\title{
CMR-assessed aortic arch stiffness is associated with brain tissue integrity assessed by diffusion tensor imaging in patients with hypertension
}

\author{
Michiel Sala*, Annette van den Berg - Huysmans, Jeroen van der Grond, Anne Brandts, Albert de Roos,
} Jos J Westenberg

From 18th Annual SCMR Scientific Sessions

Nice, France. 4-7 February 2015

\section{Background}

Increased aortic stiffness may lead to insufficient flow wave dampening and subsequent transmission of excessive pulsatile energy towards end-organs such as the brain. It has been shown that CMR-assessed aortic stiffness may augment cerebral small vessel disease in patients with hypertension, as assessed by conventional structural magnetic resonance imaging (MRI). However, in addition to these overt brain abnormalities, currently it is unknown whether aortic stiffening relates to subtle changes in brain tissue integrity, which may be a precursor to overt brain abnormalities. Diffusion tensor imaging (DTI) in the brain has been used to evaluate such subtle changes in tissue integrity. The aim of this study was to assess the association between aortic arch pulse wave velocity (PWV) as a marker of arterial stiffness and brain changes assessed by conventional structural MRI as well as DTI in patients with hypertension.

\section{Methods}

78 patients with hypertension ( 35 men, mean age $46 \pm 1$ years) were prospectively included. Aortic imaging was performed using 1.5T MRI. To assess PWV over the aortic arch, one-directional through-plane velocity-encoded MRI was performed, planned perpendicular to the ascending aorta and additionally transecting the proximal
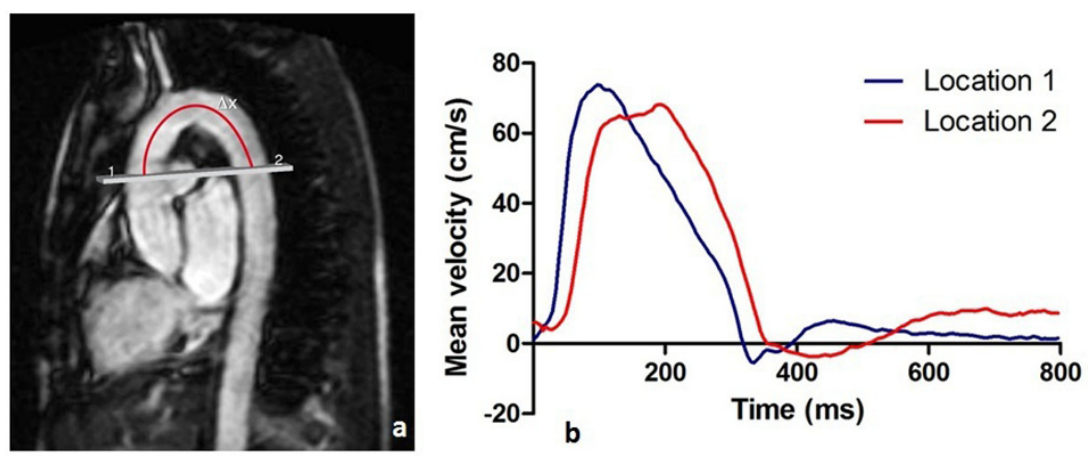

Figure 1 Aortic arch pulse wave velocity assessment: (A) Double-oblique parasagittal image of the thoracic aorta. The gray line represents the acquisition plane for one-directional through-plane velocity-encoded MRI which is positioned perpendicular to the ascending aorta (1) and additionally transects the proximal descending aorta (2). Pulse wave velocity (PWV) is determined from the propagation of the blood flow velocity, defined from the velocity-time curves recorded at locations 1 and 2 (B). PWV is defined as $\Delta x / \Delta t$, with $\Delta x$ the path length along the centerline of the aorta from positions 1 to 2 and $\Delta t$ the transit time for the foot of the velocity wave to propagate from positions 1 to 2 .

Leiden University Medical Center, Leiden, Netherlands

(c) 2015 Sala et al; licensee BioMed Central Ltd. This is an Open Access article distributed under the terms of the Creative Commons 
Table 1 Association between CMR-assessed aortic arch PWV and brain volume, white matter lesion volume, and DTI measures of brain microstructure.

\begin{tabular}{ccc}
\hline Brain volume $\left(\mathbf{c m}^{\mathbf{2}}\right)$ & $\boldsymbol{\beta}$ & P-value \\
\hline White matter & -0.22 & 0.094 \\
\hline Grey matter & -0.18 & 0.061 \\
\hline Ln white matter lesion volume $\mathbf{( m L )}$ & 0.05 & 0.713 \\
\hline FA & & \\
\hline White matter & -0.30 & $0.011^{*}$ \\
\hline Grey matter & 0.01 & 0.938 \\
\hline MD & & \\
\hline White matter & 0.31 & $0.005^{*}$ \\
\hline Grey matter & 0.28 & $0.006^{*}$ \\
\hline AxD & \\
\hline White matter & 0.24 & $0.040^{*}$ \\
\hline Grey matter & 0.27 & $0.012^{*}$ \\
\hline RD & \\
\hline Grey matter & 0.33 \\
\hline White matter & $0.002^{*}$ \\
\hline P & 0.29 \\
\hline
\end{tabular}

P-values are from linear regression analysis, adjusting for age, gender, body mass index, smoking, mean arterial blood pressure, duration of hypertension and cerebrovascular disease. FA: fractional anisotropy; MD: mean diffusivity; AxD: axial diffusivity; RD: and radial diffusivity. ${ }^{*}$ P-value $<0.05$.

descending aorta (Figure 1). Brain MRI was performed on 3.0 T MRI. Linear regression analysis was performed to assess the association between aortic arch PWV and brain macrostructure (brain volume and white matter lesion volume) and microstructure (fractional anisotropy [FA], mean diffusivity [MD], axial diffusivity [AxD], and radial diffusivity [RD] (Pierpaoli et al. Neuroimage 2001)). Models were adjusted for several cardiovascular risk factors.

\section{Results}

Aortic arch PWV was not associated with brain macrostructure. In contrast, aortic arch PWV was associated with changes in white matter (FA: $\beta=-0.30, p=0.011 ; \mathrm{MD}: \beta=$ $0.31 ; \mathrm{p}=0.005 ; \mathrm{AxD}: \beta=0.24, \mathrm{p}=0.040 ; \mathrm{RD}: \beta=0.33 ; \mathrm{p}=$ 0.002 ) and grey matter integrity (MD: $\beta=0.28, \mathrm{p}=0.006$; AxD: $\beta=0.27, p=0.012$; RD: $\beta=0.29, \mathrm{p}=0.006$ ) (Table 1 ). This effect was independent of age, gender, body mass index, smoking, mean arterial blood pressure, duration of hypertension and cerebrovascular disease.

\section{Conclusions}

Our data suggest that aortic arch stiffness is independently associated with changes in brain tissue integrity in patients with hypertension. Subtle changes in brain microstructure are related to increased stiffness of the aortic arch, even in absence of overt brain abnormalities.

\section{Funding}

N/A.

Published: 3 February 2015

doi:10.1186/1532-429X-17-S1-P401

Cite this article as: Sala et al: CMR-assessed aortic arch stiffness is associated with brain tissue integrity assessed by diffusion tensor imaging in patients with hypertension. Journal of Cardiovascular Magnetic Resonance 2015 17(Suppl 1):P401.
Submit your next manuscript to BioMed Central and take full advantage of:

- Convenient online submission

- Thorough peer review

- No space constraints or color figure charges

- Immediate publication on acceptance

- Inclusion in PubMed, CAS, Scopus and Google Scholar

- Research which is freely available for redistribution

Submit your manuscript at www.biomedcentral.com/submit
C Biomed Central 